REPORTS OF MORPHOLOGY
Official Journal of the Scientific Society of Anatomists,
Histologists, Embryologists and Topographic Anatomists
of Ukraine
journal homepage: https://morphology-journal.com

\title{
Electron microscopic changes in the skin of rats 1, 3, 7, 14, 21 and 30 days after thermal trauma on the background of the introduction for the first 7 days of $0.9 \% \mathrm{NaCl}$ solution
}

\author{
Maievskyi O.Ye. ${ }^{1}$, Mironov Ye.V. ${ }^{2}$, Galunko G.M. ${ }^{2}$, Ocheretna N.P. ${ }^{2}$, Gunas I.V. ${ }^{2}$ \\ ${ }^{1}$ Taras Shevchenko National University of Kyiv, Kyiv, Ukraine
}

${ }^{2}$ National Pirogov Memorial Medical University, Vinnytsya, Ukraine

\section{ARTICLE INFO}

Received: 2 December, 2019

Accepted: 9 January, 2020

UDC: $616-001.17: 615.451 .3$

CORRESPONDING AUTHOR

e-mail: maevskyalex8@gmail.com Maievskyi O.Ye.

\begin{abstract}
A burn wound occurs as a result of exposure to high-temperature skin or chemicals and is a serious injury with systemic effects. The problem of treatment of thermal trauma is urgent for modern medicine. Despite the fact that the overall mortality rate has dropped significantly in recent years, research about the development of new treatments and technologies for patients with skin burns is extremely important. The aim of the study is to research the features of electron microscopic changes in the skin of rats during the month after burns of II-III degree against the background of the introduction of the first 7 days of $0.9 \% \mathrm{NaCl}$ solution. Studies were performed on 180 laboratory white rats-males weighing $155-160 \mathrm{~g}$. In the course of the experiment, the animals were divided into 2 groups: 1 - rats without thermal injury, which were infused with $0.9 \% \mathrm{NaCl}$ solution at a dose of $10 \mathrm{ml} / \mathrm{kg}$; group 2 - rats which infused $0.9 \% \mathrm{NaCl}$ solution at a dose of $10 \mathrm{ml} / \mathrm{kg}$ for 7 days after skin burns. Burning skin damage was caused by applying to the lateral surfaces of the trunk of rats for 10 seconds four copper plates, heated in water at a constant temperature of $100^{\circ} \mathrm{C}$. The total area of skin lesion in rats was $21-23 \%$. Shaving of the lateral surfaces of rats' trunk, catheterization of veins, staging of skin burns, and decapitation of animals (after 1, 3, 7, 14, 21 and 30 days) were performed under intravenous propofol anesthesia (calculated at $60 \mathrm{mg} / \mathrm{kg}$ body weight). Preparations for electron microscopic examination were prepared according to the standard procedure. The data obtained were studied using a PEM-125K electron microscope. Electron microscopic studies of the skin of animals after thermal trauma under the conditions of application of $0.9 \% \mathrm{NaCl}$ solution have found that in the early stages of the experiment - the stage of shock and early toxemia (1,3, 7 days) compensatory and adaptive changes of its structural components are combined with signs of destructive disorders. In the epitheliocytes of the epidermis of the affected area of the skin is the destruction of nuclei and cytoplasm. Vascular disorders in the dermis are combined with changes in fibroblasts, an intercellular substance of fibrous connective tissue. In the late stages of the experiment - the stages of late toxemia and septicotoxemia (14, 21 and 30 days), there is a further development and deepening of destructive-dystrophic changes of all structural components of the affected skin, they become irreversible. The processes of granulation tissue formation, its transformation into connective tissue, as well as marginal epithelialization are slow. This morphological condition of the burn wound indicates the need for the use of corrective drugs to reduce destructive changes and the activation of regenerative processes in the area of skin lesions.
\end{abstract}

Keywords: skin burns, electron microscopic changes, burn wound, epidermocytes, $0.9 \% \mathrm{NaCl}$ solution.

\section{Introduction}

Thermal trauma, especially in its severe course, poses a great threat to human life. Violation of functions of vital organs causes the development of metabolic disorders in the cells and tissues of the body, endogenous intoxication, impaired immune reactivity [16]. The latter, together with high contamination of burn wounds with microflora, leads 
to the development of purulent processes and a high risk of generalization of infection. Microflora, spreading through the lymphatic and circulatory systems, worsens the course of the wound process. With inadequate treatment, prolonged stress leads to a transition from dysfunction to functional failure [8, 10-12]. It has been established that the pathogenic mechanism of pathological changes in burn disease is the numerical morphofunctional changes in the area of the affected area $[3,21]$.

The burn wound acts as a trigger mechanism that triggers all chains of pathogenesis of thermal trauma. Despite the fact that it is the systemic disorders that cause the lethal consequences and severe complications of burn disease, the treatment of the burn wound itself should be given importance, because the timely termination of pathological processes in the wound focus can significantly reduce the degree of damage to vital organs $[2,5,13,15$, 20]. That is why it is important to study the features of skin morphological changes in conditions of thermal trauma at the optical and electron microscopic levels, which will be the basis for a better understanding of pathological processes in the burn wound and the development of effective treatments.

The purpose of the study is to research the characteristics of electron microscopic changes in the skin of rats during the month after the burn of the II-III degree against the background of the introduction of the first 7 days of $0.9 \% \mathrm{NaCl}$ solution.

\section{Materials and methods}

Studies were performed on 180 laboratory white ratsmales weighing $155-160 \mathrm{~g}$. In the course of the experiment, the animals were divided into 2 groups: group 1 - rats without thermal injury which infused $0.9 \% \mathrm{NaCl}$ solution at a dose of $10 \mathrm{ml} / \mathrm{kg}$ for 7 days; group 2 - rats, which after a thermal injury of the skin for 7 days were infused $0.9 \%$ $\mathrm{NaCl}$ solution at a dose of $10 \mathrm{ml} / \mathrm{kg}$. Skin burn was caused by applying to the pre-depilated lateral surfaces of the trunk of rats for 10 seconds 4 copper plates (two plates with an area of $13.86 \mathrm{~cm}^{2}$ on each side), which were pre-heated for 6 minutes in water at a constant temperature of $100^{\circ} \mathrm{C}$ $[1,7]$. The total area of skin lesion in rats was $21-23 \%$. All solutions were injected into the inferior vena cava after catheterization in aseptic conditions through the femoral vein. Shaving of the lateral surfaces of rats' trunk, catheterization of veins, staging of skin burns and decapitation of animals were performed under the conditions of intravenous propofol anesthesia (at the rate of $60 \mathrm{mg} / \mathrm{kg}$ of body weight of the animal) [4]. Bioethics Committee of National Pirogov Memorial Medical University, Vinnytsya (protocol №1 from 11.04.2016) found that the studies were carried out taking into account the recommendations of the European Commission on conducting animal and animal health studies, medical recommendations of the State Pharmacological Center of the Ministry of Health of Ukraine and "Rules to Clinical
Pharmacovigilance (GLP) Clinical Safety Assessment".

For further in-depth study, we selected ultrastructural changes in the skin after 1, 3, 7, 14, 21 and 30 days from the start of the experiment. For ultrastructural examination, small pieces of skin were fixed with $2.5 \%$ glutaraldehyde solution on phosphate buffer $(\mathrm{pH} 7.4)$. Further fixation was performed with $1 \%$ OsO4 solution. Dehydrated in a series of alcoholic solutions of increasing concentration. Contrasted with uranyl acetate, was enclosed in a mixture of araldite with epoxy resins [9].

Electron microscopic studies were performed with the help of Doctor of Biological Sciences Prof. K.S.Volkov (Department of Histology and Embryology of the Higher Educational Institution "Gorbachevsky Ternopil State Medical University, Ministry of Health of Ukraine"). Ultrathin sections were obtained on an LKB-3 ultratome (Sweden) and contrasted them on copper support mesh uranyl acetate and lead citrate according to Reynolds. The data obtained were studied using a PEM-125K electron microscope.

\section{Results}

Electron microscopic studies of the skin of rats after thermal trauma under the conditions of application of $0.9 \%$ $\mathrm{NaCl}$ solution after 1 day have found that its structural components are characterized by reorganization characterizing the reactive changes of the organ to the damaging factor.

Destructive changes of the epidermocytes are found in the central areas of the affected skin burn. In cells of the basal and spinous layers pyknotic with homogeneous karyoplasm nucleus are observed. Perinuclear spaces are enlarged. Areas of destruction of karyolemma are also available. Damage to the cytoplasm is manifested by the destruction of organelles. Mitochondria are swollen with electron-light matrix and destructed cristae, some of them in the form of vacuole-like structures. The hyaloplasm is osmiophilic, the tonofilaments are clearly outlined in it, some of them are fragmented. The extracellular spaces are enlarged, the damage of desmosomal contacts is noted (Fig. 1).

Semidesmosomal contacts with the basement membrane are also damaged, it is unevenly thickened, poorly contoured.

The epidermocytes of the spinous and granular layers are destructively altered. Kernels, pyknotic, with electrondense karyoplasm, indistinctly contoured. The cytoplasm is homogenized, osmiophilous, fragmentation and disintegration of the tonofibrils are present. In the cells of the granular layer, large, irregularly shaped keratohyalin lumps are observed (Fig. 2).

In the dermis there is swelling of the amorphous component of the intercellular substance, fragmentation and lysis of collagen fibers. In the affected areas there are lymphocytes, degranular basophils and neutrophils, which reflects the inflammatory process in the dermis. 


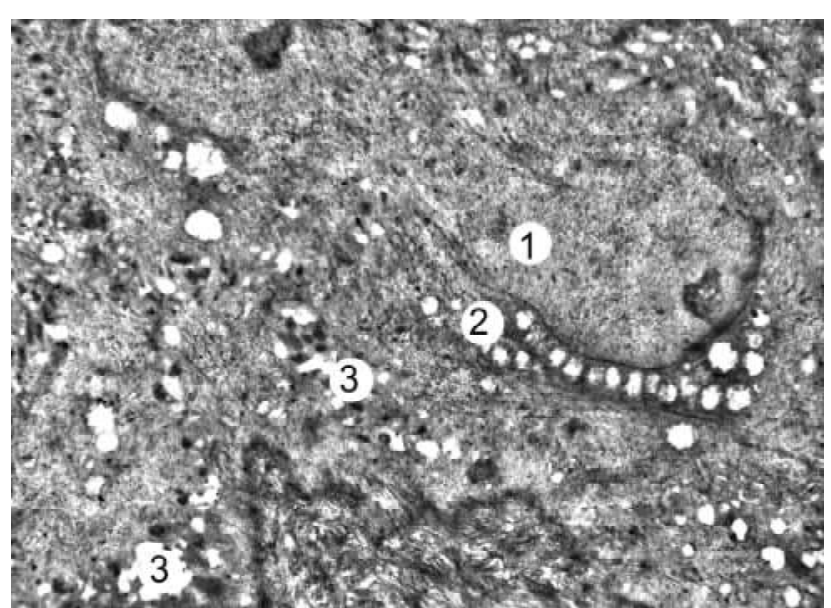

Fig. 1. Submicroscopic changes of the epidermocytes of the basal and spinous layers after 1 day after burn injury with the introduction of $0.9 \% \mathrm{NaCl}$ solution: 1 - epidermocyte nucleus, 2 - epidermocyte cytoplasm with damaged organelles, 3 - intercellular space. $x 12000$.

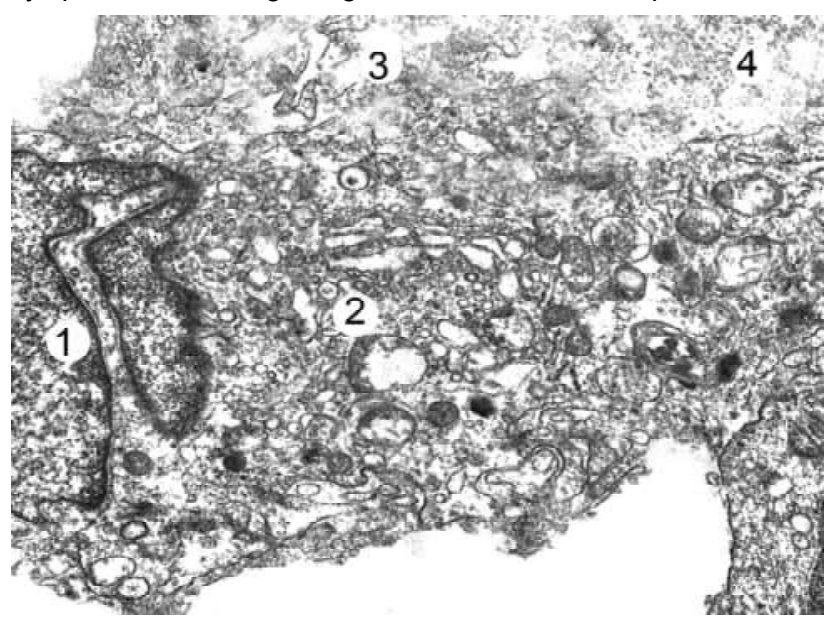

Fig. 3. Ultrastructural changes of the components of the dermis 1 day after burn injury with the introduction of $0.9 \% \mathrm{NaCl}$ solution: 1 destructured fibroblast nucleus, 2 - fibroblast cytoplasm, 3 intercellular substance swelling, 4 - fibrous structures lysis. x14000.

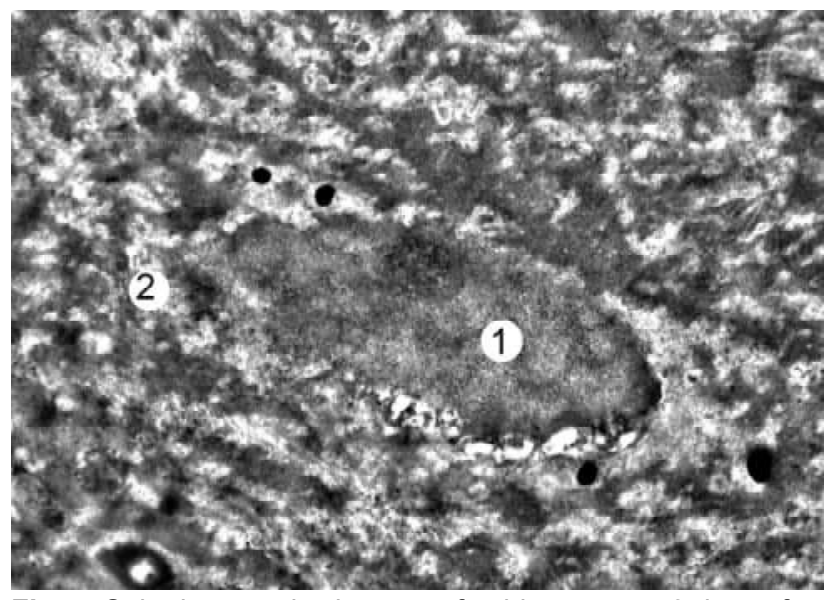

Fig. 5. Submicroscopic changes of epidermocytes 3 days after burn injury with the introduction of $0.9 \% \mathrm{NaCl}$ solution: 1 - pyknotic nucleus, 2 - damaged cytoplasm. $\times 12000$.

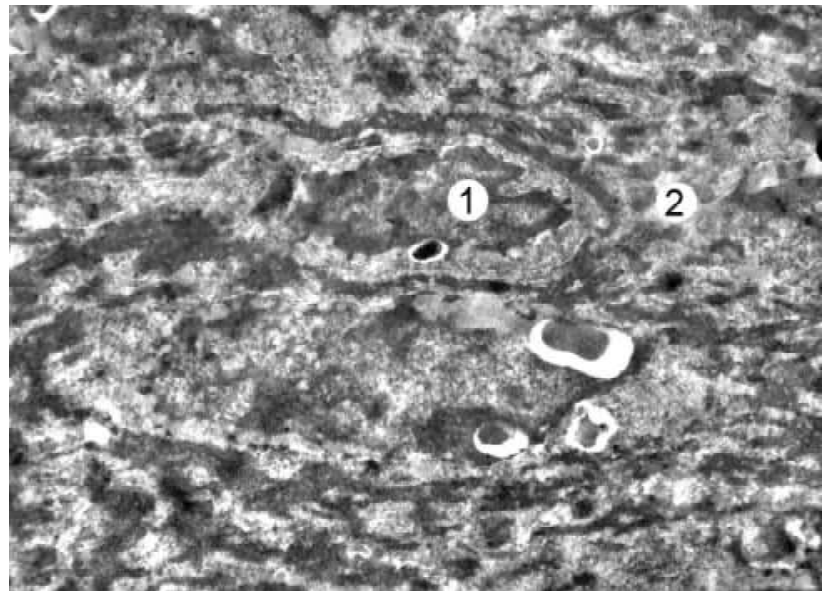

Fig. 2. Submicroscopic changes of the epidermocytes of the granular layer 1 day after burn injury with the introduction of $0.9 \%$ $\mathrm{NaCl}$ solution: 1 - pyknotic nucleus, 2 - homogenized cytoplasm. x12000.

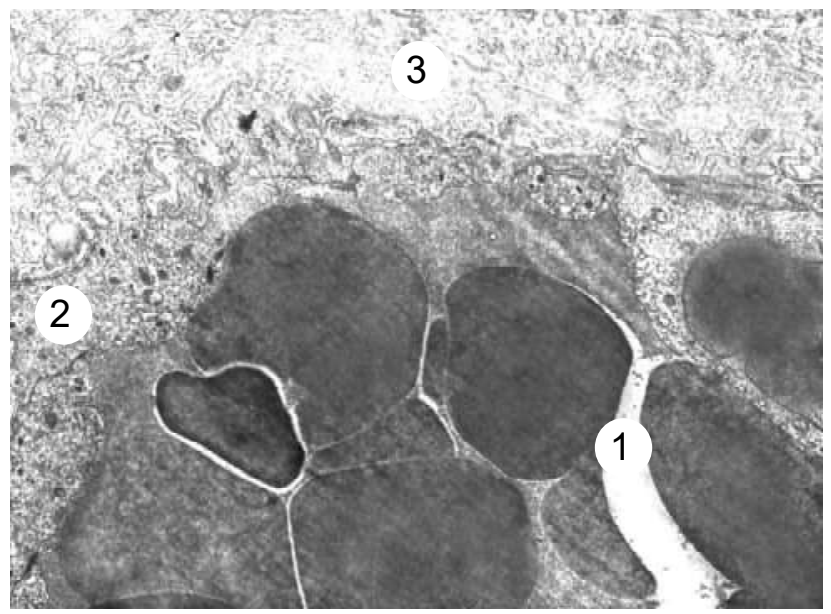

Fig. 4. Ultrastructural changes of the blood capillary of the dermis of the skin after 1 day after burn injury with the introduction of $0.9 \% \mathrm{NaCl}$ solution: 1 - enlarged, blood-filled lumen, 2 - cytoplasm of endothelial cells, 3 - perivascular edema. x7000.

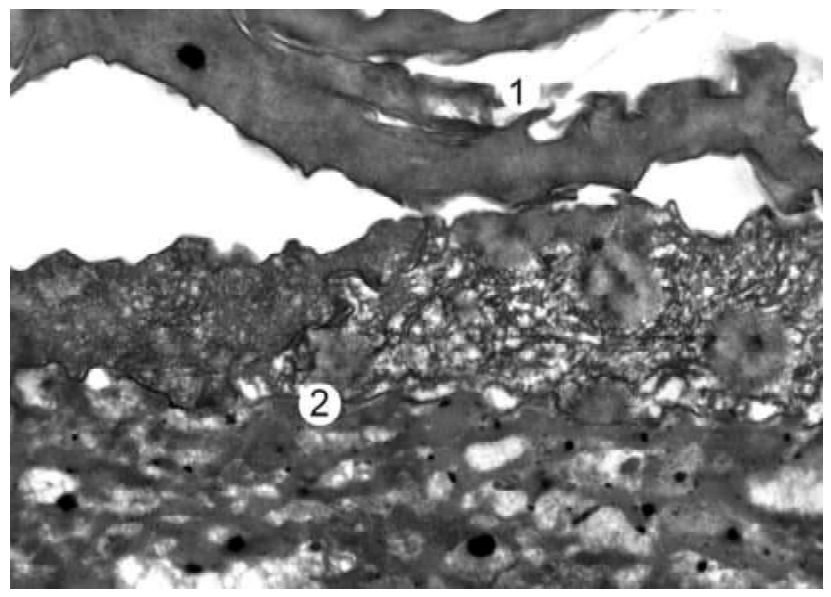

Fig. 6. Submicroscopic changes of the surface layers of the epidermis after 7 days after burn injury with the introduction of $0.9 \% \mathrm{NaCl}$ solution: 1 - detached horn scales, 2 - damaged epidermocytes. $x 17000$. 


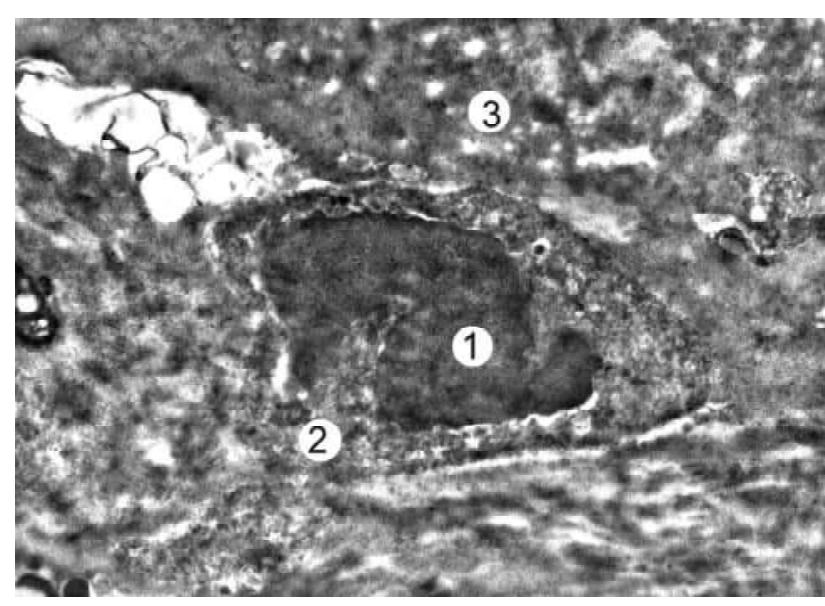

Fig. 7. Submicroscopic changes of connective tissue 7 days after burn injury with the introduction of $0.9 \% \mathrm{NaCl}$ solution: 1 pyknotic nucleus, 2 - damaged cytoplasm, 3 - intercellular substance. $\times 9000$.

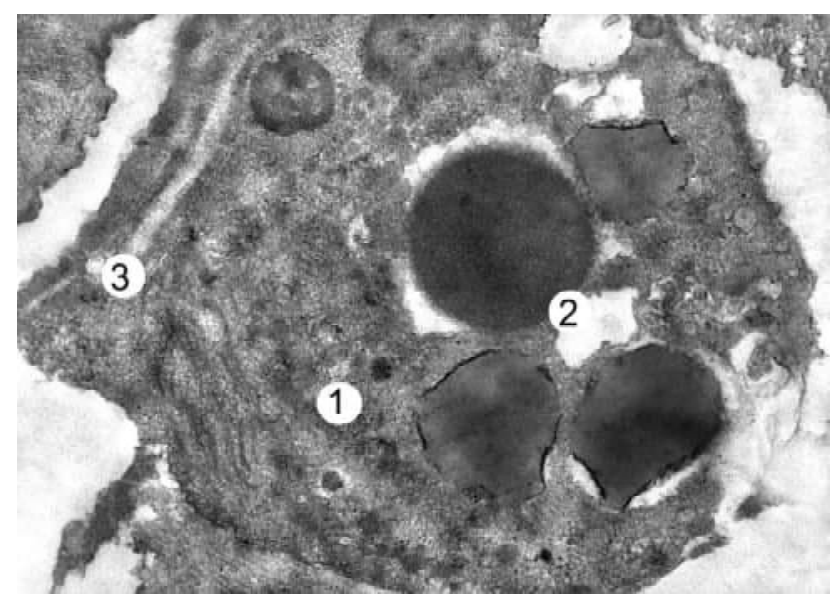

Fig. 9. Ultrastructural changes of the blood capillary after 7 days after burn injury with the introduction of $0.9 \% \mathrm{NaCl}$ solution: 1 swollen cytoplasm of endothelial cells, 2 - erythrocytes, 3 - damaged capillary wall. $x 12000$.

In fibroblasts destruction of the nucleus and organelles. The nuclei are irregular in shape, dominated by heterochromatin. In the cytoplasm, the tubules of the granular endoplasmic reticulum and the Golgi cistern are unevenly expanded and vacuolated. The mitochondria are hypertrophied, the matrix is enlightened with signs of edema, the cristae are destroyed. The number of lysosomes is increasing (Fig. 3).

The gaps of the blood capillaries are full-blooded, enlarged. The cytoplasm of endothelial cells is enlightened, in the state of edema, the organelles are damaged, the number of foamy cytosis is smaller. The basement membrane is slightly contoured, unevenly thickened (Fig. 4).

Subsequently ( 3,7 days of study) necrobiotic changes in the central and marginal areas of the wound grow. The epidermocytes of all layers of the epidermis are necrotically damaged, in many cells pyknosis and karyorrhexis of the nuclei are present (Fig. 5). Their cytoplasm is electron-

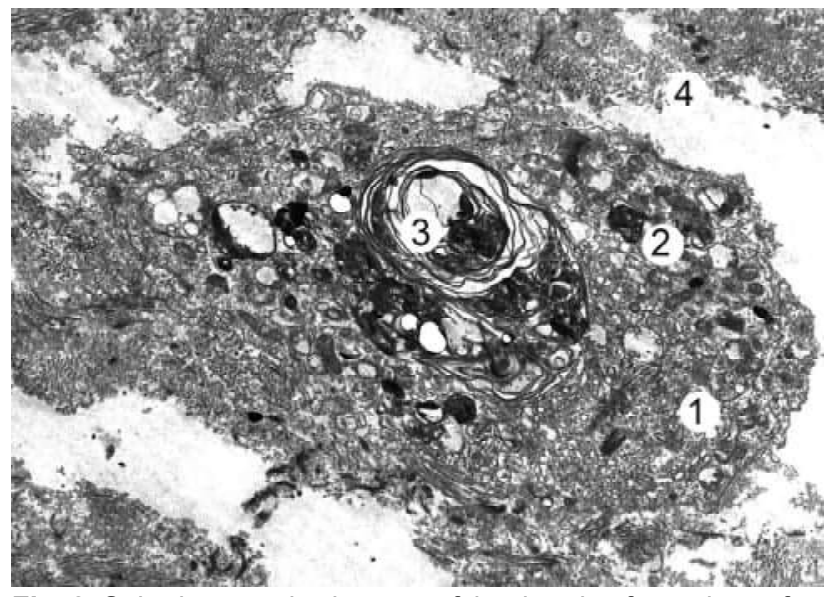

Fig. 8. Submicroscopic changes of the dermis after 7 days after burn injury with the introduction of $0.9 \% \mathrm{NaCl}$ solution: 1 - cytoplasm of macrophages, 2 - autophagosomes, 3 - residues of the destroyed cell, 4 - intercellular substance. $x 9000$.

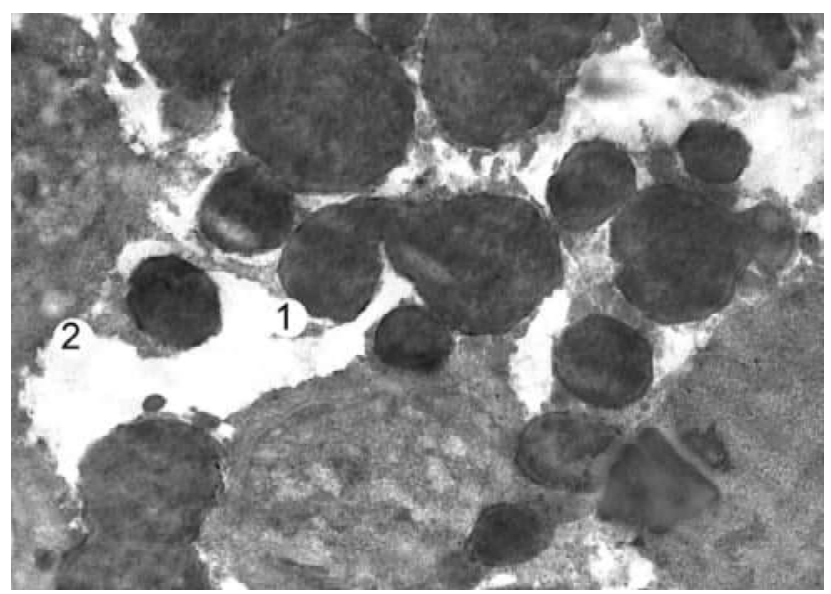

Fig. 10. Ultrastructural changes of the blood capillary of the dermis of the skin 14 days after burn injury with the introduction of $0.9 \%$ $\mathrm{NaCl}$ solution: 1 - capillary plethora, 2 - destroyed cytoplasm of endothelial cells. $x 7000$.

dense homogenized, organelles are destructed. Intercellular spaces enlarged, horn scales flaked (Fig. 6).

In the stage of early toxemia in the central area of the wound revealed deep necrotic changes in the dermis. Fibroblasts and fibrocytes have an osmiophilic hyaloplasm in which damaged organelles are present. The tubules of the granular endoplasmic reticulum and the Golgi cisterns are irregularly expanded, fragmented on the membranes of the endoplasmic reticulum. Significantly altered mitochondria, they destroyed not only the cristae, but also the focal outer membrane. Some organelles are vacuoleshaped and have an electron-light matrix. The nuclei are pyknotic, having an osmiophilic karyoplasm, irregular shape, deep invasions of the karyolemma (Fig. 7).

The established changes in the ultrastructure of fibroblasts indicate inhibition of their synthetic activity, which significantly affects the state of the intercellular substance. The inflammatory reaction of the dermis, the formation of a demarcation shaft in the wound is accompanied by an 


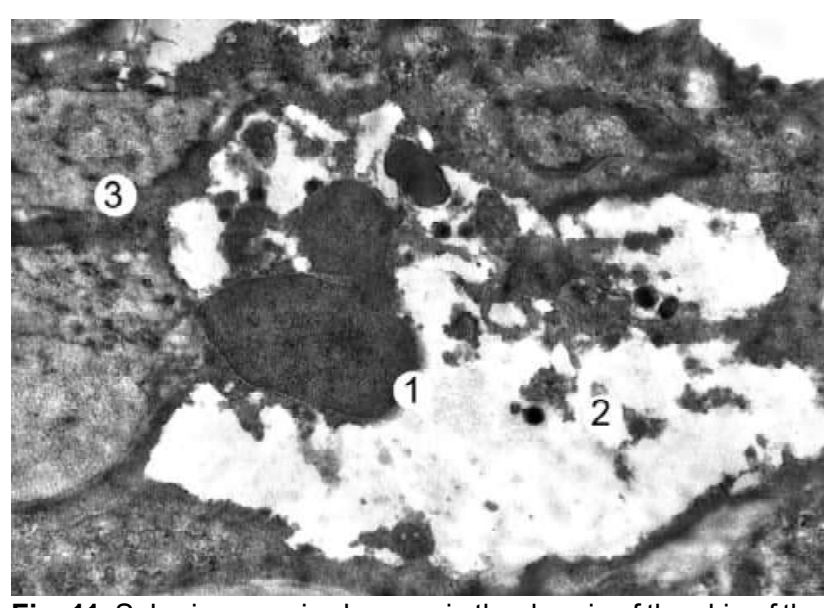

Fig. 11. Submicroscopic changes in the dermis of the skin of the animal 14 days after burn injury with the introduction of $0.9 \% \mathrm{NaCl}$ solution: 1 - nucleus fragment, 2 - fibroblast cytoplasm, 3 homogenized intercellular substance. x9000.

increase in the number of lymphocytes, neutrophils, macrophages. In lymphocytes osmiophilic karyoplasm of nuclei, fuzzy karyolemma, in the cytoplasm damaged organelles. The cytoplasm of neutrophilic leukocytes is degranularized, contains numerous autophagosomes. Macrophage plasmolemma forms significant outgrowths and invaginations. In their cytoplasm, phagosomes and osmiophilous residual bodies are detected (Fig. 8).

In the intercellular substance, the fibrous structures are sophisticated, fragmented. Hemocapillary lumens are fullblooded enlarged, there is swelling of the cytoplasm of endothelial cells, organelles are destructed, the basement membrane is not clearly contoured, of uneven thickness. Hemocapillaries with the ruptured wall and hemorrhage were detected (Fig. 9).

After 14 days, the burn wound under the scab is represented by a structureless dermis, which includes fragments of destroyed cells placed in the swollen intercellular substance. Fragmented collagen and elastic fibers are present in the wound. The endothelial cytoplasm and the basement membrane are disturbed in the walls of the blood capillaries. This leads to hemorrhage, and erythrocytes are often found in the extracellular substance (Fig. 10). Modified neutrophilic leukocytes and macrophages are also present in the damaged dermis. The formation of connective tissue in the wound is inhibited by the destruction of the protein synthesis organelles and energy supply in the fibroblasts (Fig. 11). In the marginal areas of the wound during this period of study, the proliferation of epidermal cells is suppressed. The nucleus and cytoplasm are destructively altered in the germinal epidermocytes. The basement membrane is poorly contoured.

Submicroscopic examination of the affected area of the animal skin in the long term (21-30 days) - the stage of late toxemia and septicotoxemia after thermal trauma showed that in the wound the structure of the epidermis and dermis

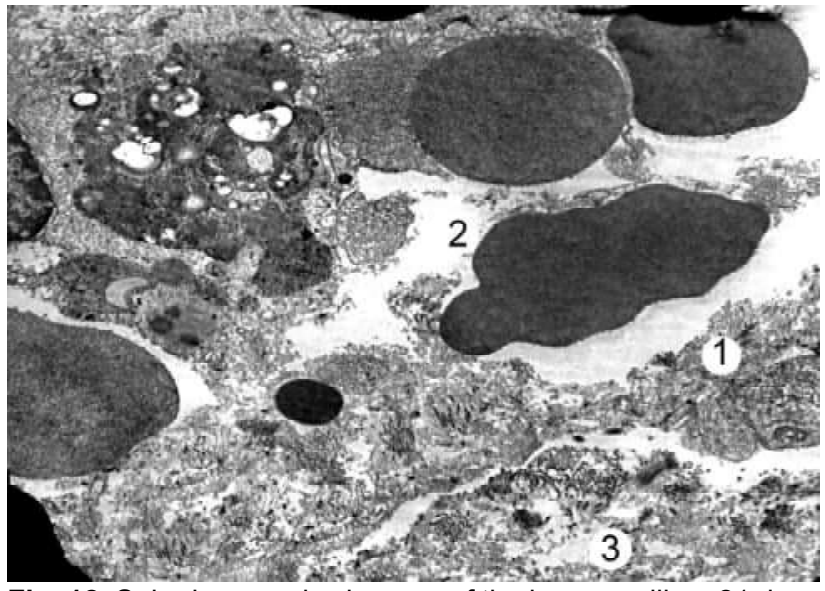

Fig. 12. Submicroscopic changes of the hemocapillary 21 days after burn injury with the introduction of $0.9 \% \mathrm{NaCl}$ solution: 1 destroyed endothelial cell, 2 - capillary lumen, 3 - intercellular substance. x9000.

are similar to the previous term of the experiment. In the damaged dermis, there is no boundary between the papillary and mesh layers due to the destruction of the fibrous structures and homogenization of the intercellular substance. Defective walls of many blood capillaries are present. This leads to perivascular edema and hemorrhage (Fig. 12). The established ultrastructural changes of the hemocapillaries of the burn wound aggravate its trophism, promote hypoxia, and inhibit regeneration.

In the long term, the granulation tissue is poorly formed in the wound. Destructively altered fibroblasts with osmiophilic, pyknotic nuclei are observed. Deep invaginations of their karyolemma lead to karyorrhexis. In electron-dense cytoplasm, there are destructured organelles, fragmented, thickened tubules of granular endoplasmic reticulum and cisterns of the Golgi complex. Numerous hypertrophied mitochondria have a light matrix and few cristae (Fig. 13).

The intercellular substance in the central and peripheral areas of the wound is swollen. It has lymphocytes with small pyknotic nuclei, neutrophils and basophils that degranulate. There are also macrophages, the cytoplasm of which contains different in size, mainly rounded autophagosome (Fig. 14).

In the marginal areas of the burn wound in the preserved epidermis, there is a regeneration of the epidermocytes of the germ layer, but it is insignificant. Only individual cells have nuclei with large nuclei and ribosomal granules in the karyoplasm, and the signs of mitotic division are isolated. In many epidermocytes, osmiophilic nuclei with karyolemma invaginations are noted, organelles and tonofilaments are damaged in the cytoplasm. This indicates an inhibition of intracellular regeneration in them.

The intercellular spaces are foci enlarged in some places, and the intercellular contacts are preserved only in some areas (Fig. 15). The basement membrane in the marginal area is unevenly thickened, swollen. 


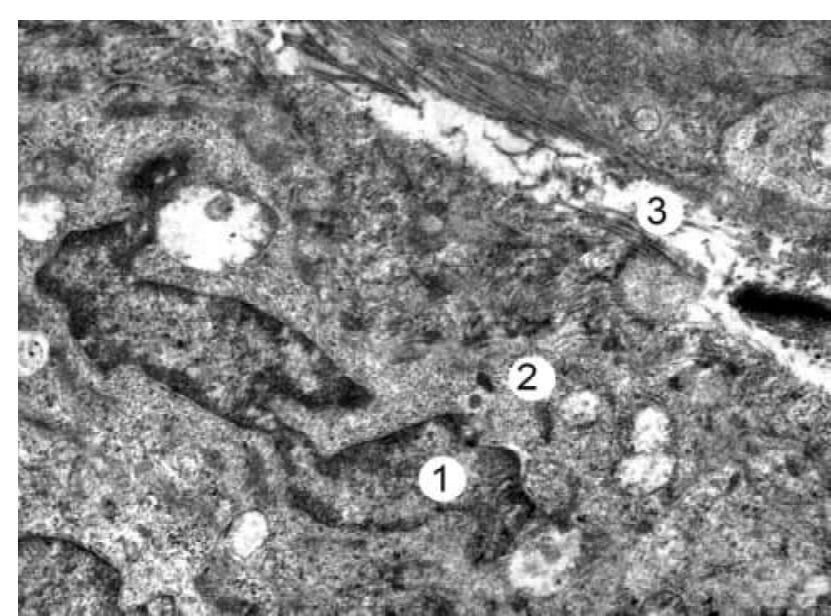

Fig. 13. Submicroscopic changes of fibroblast and intercellular substance of dermis of animal skin after 21 days after burn injury with introduction of $0.9 \% \mathrm{NaCl}$ solution: 1 - pyknotic fibroblast nucleus, 2 - fibroblast cytoplasm, 3 - intercellular substance. x9000.

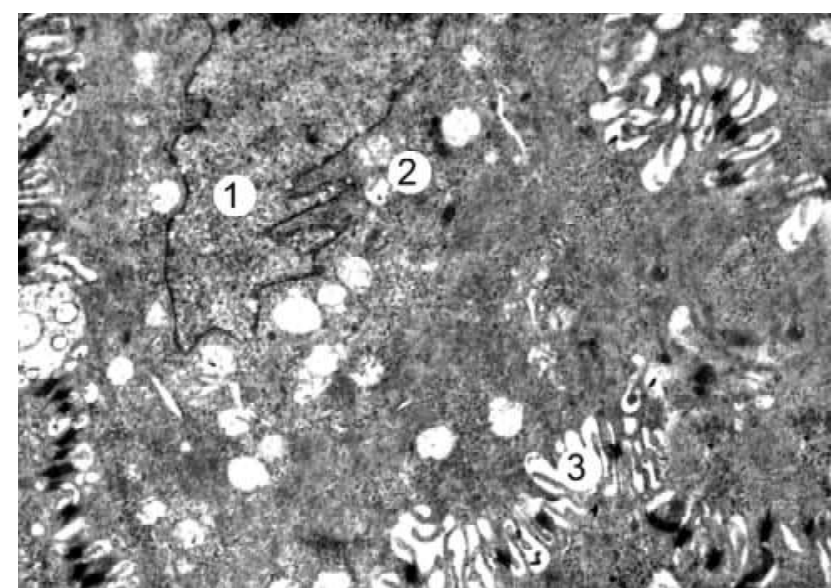

Fig. 15. Submicroscopic condition of epidermocyte of marginal area of wound of animal skin 30 days after burn injury with introduction of $0.9 \% \mathrm{NaCl}$ solution: 1 - nucleus, 2 - mitochondria, 3 - intercellular contacts. x9000.

Hemocapillary lumens full-blooded, expanded. The cytoplasm of endothelial cells in their walls with signs of edema. However, perivascular edema, destruction of the basement membrane and hemorrhage are less (Fig. 16).

\section{Discussion}

The revealed features of electron microscopic changes in the skin of rats at different periods after thermal trauma confirm the available data in the scientific literature. It was established that deep destruction of the epidermocytes was observed at the 7th day after skin burns in the marginal and central areas of the wound. Much of the cells of the basal and spinous layers of the epidermis had nuclei with signs of pyknosis. Intercellular contacts were broken. Deep necrosis of the dermis of the skin was combined with the destruction of the components of its vascular system. The presence of blood clots in the lumen of the capillaries was

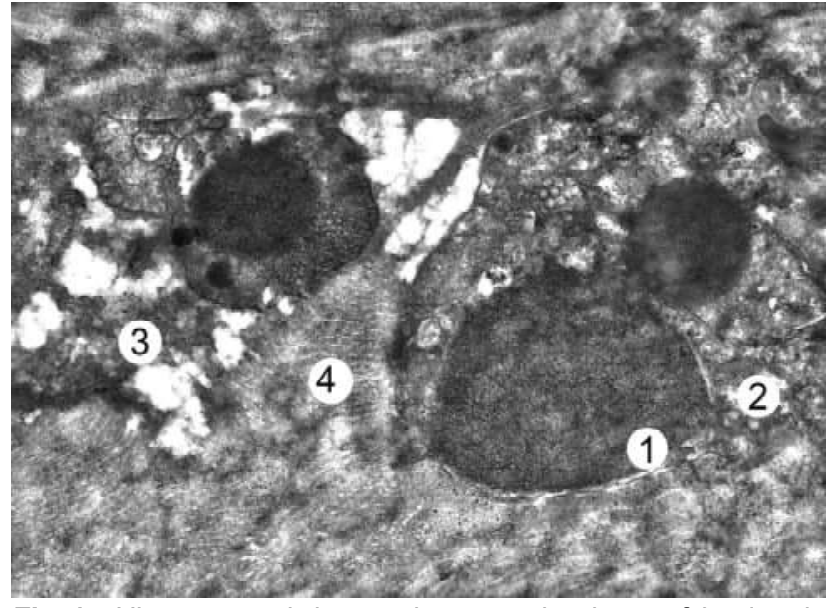

Fig. 14. Ultrastructural changes in connective tissue of the dermis of the animal's skin 30 days after burn injury with the introduction of $0.9 \% \mathrm{NaCl}$ solution: 1 - pyknotically altered lymphocyte nucleus, 2 - lymphocyte cytoplasm, 3 - cytoplasm of macrophages, 4 intercellular substance. $x 9000$.

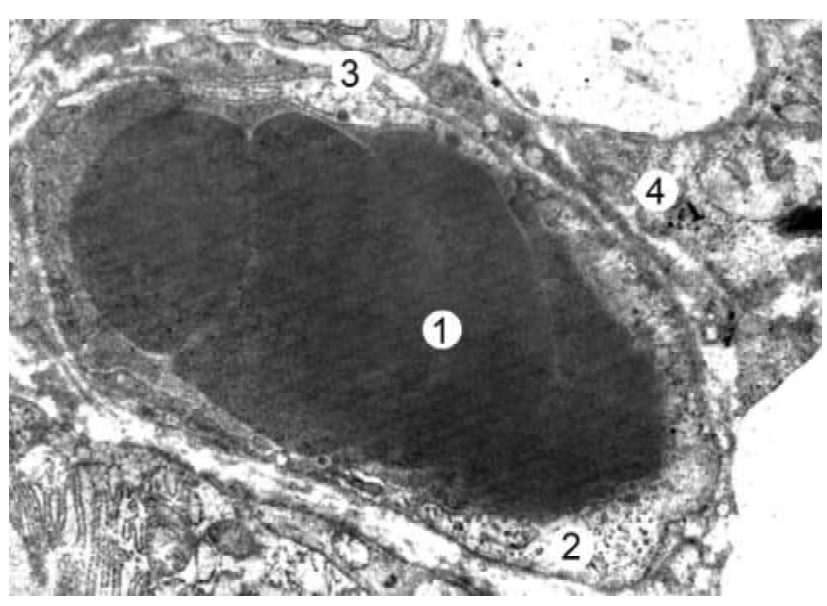

Fig. 16. Submicroscopic condition of hemocapillary of the marginal area of the skin of the animal in 30 days after burn injury with the introduction of $0.9 \% \mathrm{NaCl}$ solution: 1 - red blood cells in the lumen, 2 - cytoplasm of endothelial cells, 3 - basement membrane, 4 perivascular space. $x 9000$.

characteristic. Violation of the permeability of their wall was observed, which was accompanied by dermal edema, cellular infiltration of the connective tissue, and significant hemorrhages. On the 14th day of this study, an unformed homogeneous mass containing fragments of destroyed cells, collagen and elastic fibers was found in the wound. The blood capillaries were destructured. In addition, the keratinocytes of the germinal layer of the epidermis showed signs of inhibition of intracellular regeneration. In later periods of thermal trauma (21, 30 days), worsening of the trophism and regeneration of the affected tissues due to disorders of microcirculation were observed, and destructive changes became irreversible [14].

The study of the effect of infusion of $0.9 \% \mathrm{NaCl}$ solution on the peculiarities of morphological changes of organs and tissues in different periods of burn injury of the skin showed the presence of agreement with the data of our 
study. Thus, it was found that in the wall of the small intestine in the period from 14 to 30 days after a thermal injury of the skin under the conditions of the introduction for the first seven days of $0.9 \% \mathrm{NaCl}$ solution there were significant disturbances of the microcirculatory bed, which were manifested by the expansion or vice versa of narrowing of the lumps and uneven blood filling. Destructive changes in the cells of the epithelial lamina of the villi and the lamina of the small intestinal mucosa were observed. It is characteristic that these changes are not compensatory and adaptive and led to the further development of necrobiotic processes [6].

Electron microscopic examination of the components of the aerohematic barrier of rats after skin burns with the introduction of $0.9 \% \mathrm{NaCl}$ solution for the first seven days revealed significant reactive alveolar changes. Their blood capillaries are enlarged. There is a noticeable restructuring of the components of the aerohematic barrier in the form of uneven thickness of its wall due to swelling and enlightenment of the cytoplasmic region of the respiratory epitheliocytes. Initial signs of inhibition of regeneration and destruction of the walls of the alveoli and blood capillaries are available. On the 7 th day the thinning of the basement

\section{References}

[1] Abdullahi, A., Amini-Nik, S., \& Jeschke, M. G. (2014). Animal models in burn research. Cell Mol. Life Sci., 71(17), 32413255. doi: 10.1007/s00018-014-1612-5

[2] Berezutsky, V. I. (2018). Modern approaches to therapy of burn shock. Pain, Anesthesia and Intensive Care, 1(82), 35-40. doi: https://doi.org/10.25284/2519-2078.1(82).2018.121957

[3] Busuioc, C. J., Mogosanu, G. D., Popescu, F. C., Lascar, I., Parvanescu, H., \& Mogoanta, L. (2013). Phases of the cutaneous angiogenesis process in experimental third-degree skin burns: histological and immunohistochemical study. Rom. J. Morphol. Embryol., 54(1), 163-171. PMID: 23529325

[4] Dobrelia, N. V., Boitsova, L. V., \& Danova, I. V. (2015). Legal framework for conducting ethical expertise of preclinical studies of medicinal products using laboratory animals. Pharmacology and Drug Toxicology, 2, 95-100.

[5] Dries, D. J. \& Marini, J. J. (2017). Management of Critical Burn Injuries: Recent Developments. Korean J. Crit. Care Med., 31(1), 9-21. doi: 10.4266/kjccm.2016.00969

[6] Galunko, G. M., \& Gavryluk, A. O. (2014). Electron microscopic changes of the mucous membrane of the small intestine of rats in late stages of optic disease. World of Medicine and Biology, 4 (47), 97-101.

[7] Gunas, I., Dovgan, I., \& Masur, O. (1997). Method of thermal burn trauma correction by means of cryoinfluence. Abstracts are presented in zusammen mit der Polish Anatomical Society with the participation of the Association des Anatomistes Verhandlungen der Anatomischen Gesellschaft, Olsztyn ( $p$. 105). Jena - München : Der Urban \& Fischer Verlag.

[8] Holdzon, M. A., Dolhykh, V. T., \& Hyrsh, A. O. (2012). Violation of systemic hemodynamics, contractility and myocardial metabolism in severe thermal injury in the experiment and their correction. General Resuscitation, 8(3), 14-17.

[9] Horalskyi, L. P., Khomych, V. T., \& Kononskyi, O. I. (2011). Fundamentals of histological technique and morphofunctional methods of research in normal and pathology. Zhytomyr: membrane of hemocapillaries was characteristic. Alveolocytes II showed signs of swelling and vacuolation, had rounded nuclei with nuclear membrane invaginations. In late terms (14, 21 days) revealed profound destructive changes of the alveolar wall, hemocapillaries and alveolar macrophages. Changes in this period were irreversible [17-19].

The established morphological condition of the burn wound indicates the need for the use of corrective drugs in order to reduce destructive changes and activate regenerative processes in the skin lesion area.

\section{Conclusions}

1. Conducted electron microscopic studies of the skin of animals after thermal injury under the conditions of application of $0.9 \% \mathrm{NaCl}$ solution found that in the early stages of the experiment (1, 3, 7 days) compensatory and adaptive changes of its structural components are combined with signs of destructive disorders.

2 . In the later stages of the study (14, 21 and 30 days) there is a further development and deepening of destructivedystrophic changes of all structural components of the affected skin, they become irreversible.

\section{Polissya.}

[10] Hur, J., Yang, H. T., Chun, W., Kim, J., Shin, S., Kang, H. L., \& Kim, H. S. (2015). Inflammatory cytokines and their prognostic ability in cases of major burn injury. Ann. Lab. Med., 35(1), 105-110. doi: 10.3343/alm.2015.35.1.105

[11] Kallinen, O., Maisniemi, K., \& Boheing, K. (2012). Multiple organ failure as cause of death in patients with severe burns. $J$. Burn Care Res, 33(2), 206-211. doi: 10.1097/ BCR.0b013e3182331e73

[12] Klychnykova, E. V., Tazyna, E. V., Smyrnov, S. V., Spyrydonova, T. G., Zhyrkova, E. A., Borysov, V. S., \& Godkov, M. A. (2015). Interrelation of biochemical indicators of oxidative stress, endogenous intoxication and regulation of vascular tone in patients with burn injury. Anesthesiology and Intensive Care, (1), 45-49.

[13] Kovalenko, O. M. (2014). Issues of infusion therapy for burn shock. Surgery of Ukraine, (2), 13-19.

[14] Kramar, S. B., Volkov, K. S., \& Pyda, V. P. (2014). Submicroscopic changes of burn wound in experimental thermal trauma. Reports of Morphology, 20(1), 140-142.

[15] Masood, R. A., Wain, Z. N., Tariq, R., Ullah, M. A., \& Bashir, I. (2016). Burn Cases, Their Management and Complications: A Review. International Current Pharmaceutical Journal, 5(12), 103-105. doi: 10.3329/icpj.v5i12.30411

[16] Matveev, S. B., Smyrnov, S. V., \& Tazyna, E. V. (2013). The dynamics of endogenous intoxication in patients with extensive burns. Clinical Laboratory Diagnostics, 2, 10-12.

[17] Nebesna, Z. M., \& Volkov, K. S. (2011). Ultrastructural changes of the components of the aerohematic barrier in the stage of burn disease toxemia. Ukrainian Morphological Almanac, 9(3), 191-192.

[18] Nebesna, Z. M., (2014). Submicroscopic changes of the components of the air-barrier barrier in the long term after the experimental thermal trauma. World of Medicine and Biology, 1(43), 138-142. 
[19] Ocheretniuk, A. O., Nebesna, Z. M., Gunas, I. V., Yakovlieva, O. O., \& Palamarchuk, O. V. (2013). Electron microscopic changes in the respiratory department of the lungs of rats after thermal injury of the skin under the conditions of application of $\mathrm{NaCl}$ solution. World of Medicine and Biology, 2(42), 38-41.

[20] Renneberg, B., Ripper, S., Schulze, J., Seehausen, A., Weiler, M., Wing, G., Hartmann, B., ... Liedl, A. (2014). Quality of life and predictors of long-term outcome after severe burn injury. J. Behav. Med., 37(5), 967-976. doi: 10.1007/s10865-0139541-6

[21] Rowan, M. P., Cancio, L. R., Elster, E. A., Burmeister, D. M., Rose, L. F., Natesan, S., Chan, R. K., ... Chung, K. K. (2015). Burn wound healing and treatment: review and advancements. Crit. Care, 19, 1-12. doi: 10.1186/s13054-015-0961-2

\section{ЕЛЕКТРОННО-МІКРОСКОПІЧНІ ЗМІНИ В ШКІРІ ЩУРІВ ЧЕРЕЗ 1, 3, 7, 14, 21 ТА 30 ДІБ ПІСЛЯ ТЕРМІЧНОЇ ТРАВМИ НА ФОН ВВЕДЕННЯ ПЕРШИХ 7 ДІБ 0,9\% РОЗЧИНУ NАСL \\ Маєвський О.Є., Міронов Є.В., Очеретна Н.П., Галунко Г.М., Гунас І.В.}

Опікова рана виникає внаслідок дії на шкіру високої температури або хімічних речовин та належить до важких травм із системними наслідками. Проблема лікування термічної травми є актуальною для сучасної медицини. Незважаючи на те, що загальний рівень смертності значно знизився протягом останніх років, надзвичайно важливими є дослідження, присвячені розробиі новітніх засобів та технологій лікування пацієнтів з опіками шкіри. Метою роботи є вивчення особливостей електронно-мікроскопічних змін в шкірі щурів протягом місяия після опіку II-III ступеня на фоні введення перших 7 діб 0,9\% розчину $\mathrm{NaCl}$. Дослідження проведені на 180 лабораторних білих шурах-самиях масою 155-160 г. В ході експерименту всі тварини були розподілені на 2 групи: 1 - щури без термічної травми, котрим проводили інфрузію 0,9\% розчину $\mathrm{NaCl}$ у дозі 10 мл/ке; 2 група - щури, котрим протягом 7 діб після опіку шкіри проводили інсрузію 0,9\% розчину NaCl у дозі 10 мл/кг. Опікове пошкодження шкіри викликали шляхом прикладання до бічних поверхонь тулуба щурів на 10 секунд чотирьох мідних пластинок, нагрітих у воді з постійною температурою $100^{\circ} \mathrm{C}$. Загальна площа ураження поверхні шкіри у щурів складала $21-23 \%$. Гоління бокових поверхонь тулуба щурів, катетеризацію вен, постановку опіків шкіри та декапітацію тварин (через 1, 3, 7, 14, 21 та 30 діб) проводили в умовах внутрішньовенного пропофолового наркозу (із розрахунку 60 мг/кг маси тіла тварини). Препарати для електронно-мікроскопічного дослідження готували за стандартною методикою. Вивчення отриманих даних проводили за допомогою електронного мікроскопа ПЕМ-125К. Проведені електронно-мікроскопічні дослідження шкіри тварин після термічної травми за умов застосування 0,9\% розчину $\mathrm{NaCl}$ встановили, що в ранні терміни експерименту - стадії шоку та ранньої токсемії (1, 3, 7 доби), компенсаторно-пристосувальні зміни їі структурних компонентів поєднуються 3 ознаками деструктивних порушень. В епітеліоцитах епідермісу ураженої ділянки шкіри відбувається деструкція ядер $i$ цитоплазми. Судинні розлади в дермі поєднуються зі змінами фібробластів, міжклітинної речовини волокнистої сполучної тканини. У пізні терміни експерименту - стадії пізньої токсемії та септикотоксемії (14, 21 та 30 доби) відбувається подальший розвиток та поглиблення деструктивно-дистрофрічних змін всіх структурних компонентів ураженої шкіри, вони набувають незворотного характеру. Сповільнено відбуваються процеси формування грануляційної тканини, їі перетворення в сполучну тканину, а також крайова епітелізація. Такий морфологічний стан опікової рани свідчить про необхідність застосування корегуючих препаратів з метою зменшення деструктивних змін та активації регенераторних процесів у ділянці ураження шкіри.

Ключові слова: опіки шкіри, електронно-мікроскопічні зміни, опікова рана, епідермоцити, 0,9\% розчин $\mathrm{NaCl}$.

\section{ЭЛЕКТРОННО-МИКРОСКОПИЧЕСКИЕ ИЗМЕНЕНИЯ В КОЖЕ КРЫС ЧЕРЕЗ 1, 3, 7, 14, 21 И 30 СУТОК ПОСЛЕ ТЕРМИЧЕСКОЙ ТРАВМЫ НА ФОНЕ ВВЕДЕНИЯ ПЕРВЫХ 7 ДНЕЙ 0,9\% РАСТВОРА NACL \\ Маевский А.Е., Миронов Е.В., Галунко А.М., Очеретная Н.П., Гунас И.В.}

Ожоговая рана возникает вследствие воздействия на кожу высокой температуры или химических веществ и принадлежит к тяжелым травмам с системными последствиями. Проблема лечения термической травмы является актуальной для современной медицины. Несмотря на то, что общий уровень смертности значительно снизился в последние годы, чрезвычайно важны исследования, посвященные разработке новейших средств и технологий лечения пациентов с ожогами кожи. Целью работы является изучение особенностей электронно-микроскопических изменений в коже крыс в течение месяца после ожога II-III степени на фроне введения первых 7 дней 0,9\% раствора NaCl. Исследования проведены на 180 лабораторных белых крысах-самцах массой 155-160 е. В ходе эксперимента животных были разделены на 2 группы: 1 крысы без термической травмы, которым проводили инфузию 0,9\% раствора $\mathrm{NaCl}$ в дозе 10 мл/ке; 2 группа - крысы, которым в течение 7 суток после ожога кожи проводили инфузию 0,9\% раствора $\mathrm{NaCl}$ в дозе 10 мл/кг. Ожоговое повреждение кожи вызвали путем приложения к боковым поверхностям туловища крыс на 10 секунд четырех медных пластинок, нагретых в воде с постоянной температурой $100^{\circ} \mathrm{C}$. Общая площадь поражения поверхности кожи у крыс составляла 2123\%. Бритье боковых поверхностей туловища крыс, катетеризацию вен, постановку ожогов кожи и декапитацию животных (через 1, 3, 7, 14, 21 и 30 суток) проводили в условиях внутривенного пропофолового наркоза (из расчета 60 мг/кг массы тела животного). Препараты для электронно-микроскопического исследования готовили по стандартной методике. Изучение полученных данных проводили с помощью электронного микроскопа ПЭМ-125К. Проведенные электронномикроскопические исследования кожи животных после термической травмы в условиях применения 0,9\% раствора $\mathrm{NaCl}$ установили, что в ранние сроки эксперимента - стадии шока и ранней токсемии (1, 3, 7 суток), компенсаторноприспособительные изменения ее структурных компонентов сочетаются с признаками деструктивных нарушений. $B$ эпителиоцитах эпидермиса пораженного участка кожи происходит деструкция ядер и цитоплазмы. Сосудистые расстройства в дерме сочетаются с изменениями фибробластов, межклеточного вещества волокнистой соединительной ткани. В поздние сроки эксперимента - стадии поздней токсемии и септикотоксемии (14, 21 и 30 суток) происходит дальнейшее развитие и уәлубление деструктивно-дистрофических изменений всех структурных компонентов пораженной кожи, они приобретают необратимый характер. Замедленно происходят процессы формирования грануляционной ткани, 
ее преобразования в соединительную ткань, а также краевая эпителизация. Такое морфологическое состояние ожоговой раны свидетельствует о необходимости применения корректирующих препаратов с целью уменьшения деструктивных изменений и активации регенераторных процессов в области поражения кожи.

Ключевые слова: ожоги кожи, электронно-микроскопические изменения, ожоговая рана, эпидермоциты, 0,9\% раствор $\mathrm{NaCl}$. 